\title{
From the desk of Editor-in-Chief
}

doi: http://dx.doi.org/10.3329/jemc.v8i1.35427

\begin{abstract}
Alhamdulillah! We have already completed seven years of publication of Journal of Enam Medical College. This is the $7^{\text {th }}$ anniversary issue of Journal of Enam Medical College. This is a great success and landmark in the trajectory of the journal. We share this success with the contributors, reviewers, faculties and authority of the college without whose active support and cooperation it would not have been possible to publish the journal regularly and timely. We feel very grateful to all of them.
\end{abstract}

Journal of Enam Medical College is already indexed in many indexing databases. The flow of paper submission for publication in the Journal of Enam Medical College continues to be very good. Papers are flowing in also from outside the country. This has been because of the quality of the journal and regular and timely publication.

Participation in the national and international conferences and workshops promotes exchange of ideas among professionals. During the last four months period six teachers of Enam Medical College participated in scientific conferences abroad. Their participation in these conferences and workshops greatly acquainted Enam Medical College among the professionals attending these conferences. We congratulate all of them.

With all the best wishes.

\section{Prof. Md. Aminul Haque Khan}

Editor-in-Chief 